Journal of Law \& Social Studies (JLSS)

Volume 1, Issue 2, pp 69-76, 2019

www.advancelrf.org

\title{
INDO-USA Nuclear Deal: Implications for Pakistan
}

\author{
Khadija Murtaza \\ PhD Research Scholar, Department of Political Science \& IR, \\ GC, University Faisalabad \\ Email\#khadijamurtaza12@yahoo.com \\ Dr. Mian Muhammad Azhar \\ Assistant Professor, Department of Political Science \& IR, \\ GC, University Faisalabad \\ Email\# muhammad.azhar@gcuf.edu.pk
}

\begin{abstract}
In the arena of international system, every state tries to maximize its own power for its self-survival. States are enhancing their power to increase their hegemony. That is why India and United States have led to a strategic partnership due to mutual interests in global politics such as promoting democracy and fighting terrorism. After that, they extend their collaboration across the economy, technology and atomic energy. In the South Asian security environment, the United States of America (USA) and India have a strong bond of strategic partnership due to the power struggle between the regional powers. India and USA started nuclear deal on 2005 which was completed on 2006. Behind this deal, both states increase their influence in this region. India seeks lasting partnerships with USA to achieve its strategic ambitions. The partnership of nuclear agreement between the USA and India will gain longterm national interests. This research highlights complex present-day demonstration of demonic incidence which emerged after this relationship and its implications on Pakistan.
\end{abstract}

Keywords: Hyde Act deal, 123 agreements, Smiling Buddha, deterrence, Impacts, Law Violation

\section{Introduction}

Every state tries to maximize its own power for its self-survival and hegemony in arena of international system. USAIndia bilateral relations and civil nuclear deal for transformations of new technology is the corner stone in the relations of both states in strategic partnership. USA wants to oppose the China's influence and other side India counters the Pakistan's influence in the region by strategic cooperation. India imagines a major role for itself in the current world order. USA helps India to increase their influence in the region. Indo-US relationship creates threatening situation for South Asian countries especially for Pakistan.

Meanwhile there are many reasons behind Indo-USA nuclear deal like India maintain status in region, gaining seat in Nuclear Suppliers Group (NSG), counter Pakistan and compete the China in global and regional power race, improve its economy, establish its good relations with western states and make strong hold in Afghanistan with the help of United States of America. It affected Pakistan's domestic, regional and bilateral position and relations. Strategic partnership between India and United States became a hot topic among world politics. Moreover, this paper explores the point to which India-USA relations on nuclear deal has exaggerated military developments, stability and deterrence in South Asia. But there has been more important discussion on its implication for Pakistan. The negative impact IndoUSA nuclear is that it increases the production and transfer of new weapon system for instance missile defense which would subvert and destabilize the strategic balance in South Asia and activate the arm race in region. This work analyzes the Indo-US nuclear deal and its impact on the development and stability in the region and especially on Pakistan. The research paper highlights the complex present demonstration of this internal deal after analyzing the historical milieu of this issue in South Asia.

\section{Methodology}

Deterrence theory reemerged as a strategic concept evolved during the Cold War. The conventional deterrence occurs the country has non-nuclear forces and nuclear deterrence occurs because of the nuclear forces a country has. The act

Doi.org/10.52279/jlss.01.02.6976 
of deterring especially is a nuclear attack by the threat of strike back. The concept of deterrence was started since 19th century. During the Cold War, the importance of deterrence theory increased as a military strategy with the point to the practice of nuclear weapons. At that time, it took an exclusive plan as an inferior nuclear force which would deter a more powerful adversary and provided this force that would be protected against destruction from surprise attack. In that situation deterrer must know about the attacking style, capabilities and about the level of response and include the enemy's intentions and abilities (Morgan, 2003). The deterrence theory is planned to deter opposite party or adversary from taking any action. The deterrence as strategy used for security and defense of state. It mainly focuses on the capabilities of military. It means that if we attack on other state than the rival state attack on our state (Naqvi, 2013).

In the case of India and Pakistan, both states have renowned effectiveness of nuclear deterrence. One of the Indian scientists of nuclear weapon predicted that nuclear deterrence would add stability and peace and that is only salvation for both the countries. The chance of nuclear warfare between these two states will be less than before (Jaspal Z. N., Paradox of deterrence: India-Pakistan strategic relations, 2014). This study observes the behavior in which India and Pakistan are engaged in making stable deterrence relations, particularly their nuclear policies and development of nuclear capabilities. Nuclear deterrent is good for establishing strategic stability.

\section{Historical overview of Indo-US Relations}

In the field of nuclear technology, India's relationship with USA was originated in March 1956.India's ties with United States of America have too much distrust and rift due to the development of nuclear technology by India. Indo-USA nuclear agreement is an outcome of warm relations and US aspiration to engage India as a global strategic partner. India and USA relationships were surpassed because of cold war politics. Strategic partnership involves engagement and cooperation among states that have coinciding interest and objectives. It requires from the states that are under the umbrella of strategic partnership to cooperate in the defense technology equipment and intelligence sharing. In the international relations, the possibility of cooperation and partnership is based on self-interest.

In 1974, India tested its first nuclear device which compels USA to set up London Club in 1975 to carry out the nonproliferation measures against India and the Western suppliers that asked for the Full Scope safeguards for the transfer of any future technology to other countries (Gupta, 1997).India developed its first nuclear reactor on the name of peaceful purposes titled as "Smiling Budha".India was faced to an embargo on its civil nuclear energy program after the first Pokharan test. These sanctions were severe which imposed by USA and Canada but India had continuing its collaboration in commercial nuclear power development with both states. Under the International Atomic Energy Agency safeguard, India has four power reactors that were supplied by Canada and USA before its first nuclear explosion 1974.India has originally assembled a more 13 unsafeguarded power reactors with minor modifications based on the original Canadian designs. In May 1998, nuclearization in South Asia led to several sanctions being imposed by the USA. Clinton administration's former policy was aimed at "Cap Reduce and Roll Back" the nuclear programs of New Delhi and Islamabad (Mayor, 2003). Indo-U.S. position changed in short-term by urging both states to keep their nuclear forces stable and at the lowest level. The government of India declares about the completion of underground nuclear weapons technology close to the border with Pakistan and this situation increasing fear of cloud spark.

The United States-India Peaceful Atomic Energy Cooperation Act of 2006 is a piece of legislation, presented by Congressman Henry Hyde and passed by the US Congress which creates the legal basis for co-operation between the United States and India. Hyde act that allowed the USA to sell their technology to India. The Hyde Act was passed by U.S.A to make immunity for India, to permit transfer of technology for civil nuclear energy. Hence this agreement gave a lot benefits to India to make strong its position in the region (jangir, 2012).

United States of America considered India in much of its concerns after 9/11 incident when Vajpayee regime availed this opportunity to pressurize Musharraf administration - a dictator's regime for changing its stance against Taliban. India offered all type of assistance to U.S. to decapitate Talibanisation and Al-Qaeda in Afghanistan. Subsequently, it mobilized its forces along a side of Pakistani border to exert more pressure on Islamabad to stop cross border infiltration (Chopra, 2006).India and the United States have signed different defence and nuclear treaties like Quartet Agreement in 2003. Next Step in Strategic Partnership (NSSP) in 2004, a ten-year strategic partnership Pact in June 2005 and then DTTI in 2012. On July 18, 2005 both countries entered a new era of civilian nuclear energy cooperation. India and United States signed ten-year defense framework, the Civil Nuclear Cooperation that lifted the three-decade United States moratorium on the nuclear trade with India in July 18, 2005. 
This nuclear deal that completed in 2007 formulates India the only country outside the Nonproliferation Treaty (NPT) that can participate in nuclear commerce. On July 27, 2007, U.S. and India reached an agreement on the terms and conditions of a civil nuclear cooperation deal, known as the '123 Agreement' (Karnad, 2008). 123 agreements based on the name of United States section 123 Atomic Energy Act that requires the specific agreement for transfers of material based on nuclear technology to other countries. Meanwhile there are many reasons behind Indo-USA nuclear deal like India maintain status in region, gaining seat in Nuclear Suppliers Group, balance Pakistan and compete the China in global and regional power race, improve its economy, establish its good relations with western states and make strong hold in Afghanistan with the help of United States of America. United States offered more than 17 technologies for transfer to India in the defense department in recent years. In the past years, different projects were recognized by India and United States for the co-production and cooperation of defense products based on simple technologies.

Twentieth century seemed remarkable transformation in trade, security and dramatic economic, strategic and political changes which continue to influence international relations. India changed its policies towards United States after the disintegration of USSR and USA declared as a world single powerful state. America established new policies in which all lower units are answerable to higher levels of authority in global politics.

\section{Implication for Pakistan}

Regarding to the deal's implication on Pakistan, Pakistani analysts notified that if this deal executed without inspection on India's perspective to enhance its fissile stock and nuclear weapons than it might increase arms rivalry in the region between Pakistan, India and China. The struggle of USA to undermines the Iran's and North Korea attempts to acquiring nuclear weapons but, this deal greatly contributed to the arms race in Asia. Moreover, United States had relaxed some of its limitations on technology transfer to India (Hosur, 2010).

\subsection{Indo-USA nuclear deal alarming situation for Pakistan}

By signing this deal India increases its ability to produce weapons and create alarming situation for Pakistan. India got nuclear fuel of United States to expend the production of plutonium for nuclear weapons by signing this deal. India has promised to accept safeguards which might permit India eliminate nuclear facilities for nuclear weapons from international safeguards. However, deal has not covered the fissile material. More than 500-kilogram plutonium that is enough for development of 100 nuclear weapons because Nuclear weapons are more harmful than conventional weapons. All this stock would reserve for defenses according to this deal. Due to this agreement, both India and Pakistan started arms development to counter the fear of each other. By this deal, India enjoys a substantial superiority over, its regional balancer, Pakistan (Bokhari, 2003).In the world, Pakistan is a single state which has the growing nuclear weapons and fissile material to develop above 200 nuclear devices by 2020 (tank, 2014). According to the Council on Foreign Relations (CFR), South Asia due to strategic stability in nuclear world would be at risk of breakdown in stability of region (Koblentz, 2014).

After the Indo-USA deal, Pakistan has increased its nuclear weapons production that indicated only to deter India from intervention in Pakistan's territory and defend its territorial borders. Behind this step, United States gives argument to prevent the Pakistan nuclear weapons from falling in hands of terrorist groups. But there is no need of this operation because Pakistani officials refuse that blame and report that USA interference affects the Pakistan nuclear policies and plans.

\subsection{Missile Race in South Asian States}

Indo-USA nuclear deal will allow India to develop a large amount of fissile material and nuclear weapons from unsafeguarded nuclear reactors which have harmful impact in the region (Haider, 2015). Space cooperation is a part of Indo-USA nuclear deal in which transfer of expertise and nuclear missiles technology for the development of missiles. USA expertise will help India in joint lunar mission and another nuclear weapons production also helps in ballistic missiles capabilities and Indian civilian space exploration projects (Hassan, 2014).The National Command Authority of Pakistan said that due to this agreement the Arms race as deterrence requirement would increase. There is possibility that the fissile material stockpiles of both Pakistan and India would expand. Due to this agreement, the involvement of United States and its support would increase in South Asia that would impact on the strategic balance of region. For instance, by using India, United States would get geostrategic benefits for its national interest (Kerr \& Nikitin, 2016). 
Figure 1 (Nuclear weapons of India and Pakistan)

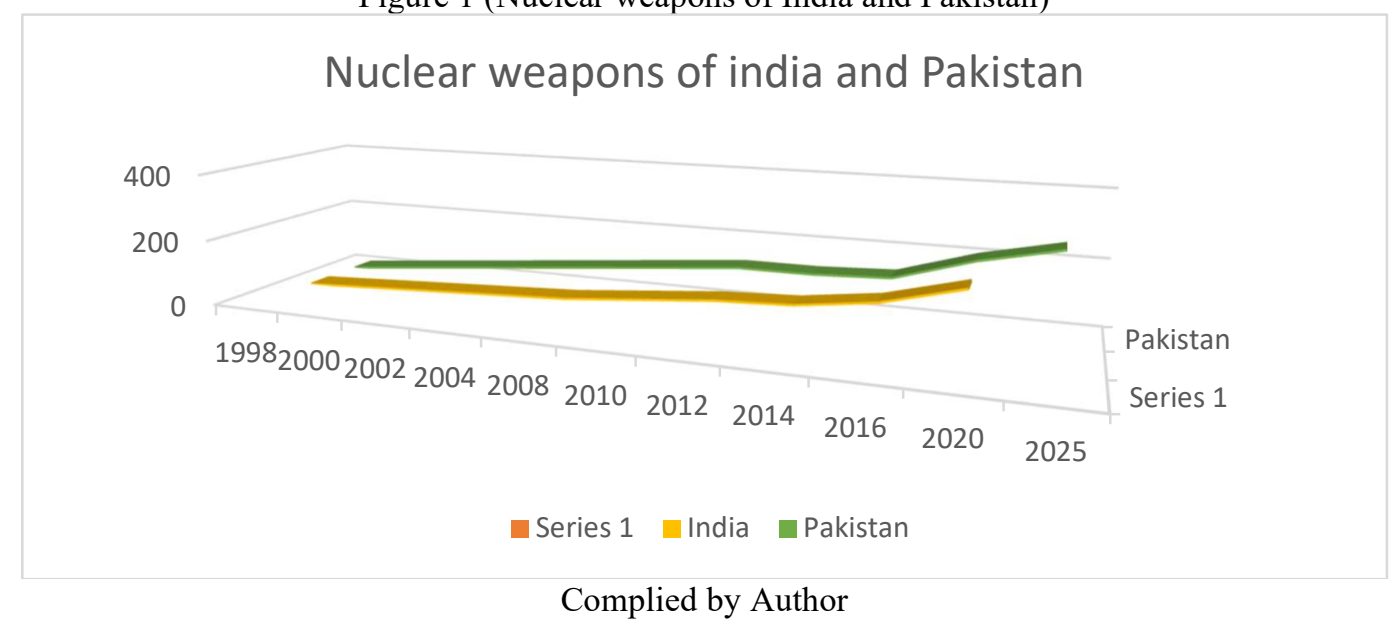

Strategic stability in South Asia is the supreme concern of the Pakistan according to Adviser of Prime Minister on Foreign Affairs Sartaj Aziz (ISSI, 2016). Pakistan always give priority to regional balance and strategic stability and called on the USA and other members of international community to support that objective. But USA deal with India shows that USA ignored the Pakistan's concerns and restarted the arms race between India and Pakistan in South Asia. Through this deal, latest technology transfers to India creating nuclear imbalance in South Asia. Due to ceasefire violations along the Line of Control by India is deteriorating the strategic imbalance between India and Pakistan. According to Sartaj Aziz, United States gave more attention to India rather than Pakistan which may jeopardize the region's stability (Haider, 2015). Furthermore, India is struggling to become a candidate for the permanent seat of United Nation Security Council and Nuclear Supplier Group, get full support from United States.

On the world level, Pakistan plays important role in encouraging stability and peace that was accepted by USA, India and Russia. USA-India cooperation undermined the regional stability and national interest of Pakistan but promoted both state's economy and strategic interests (Masood, 2015). USA adopted dual policy at a same time for two important states of South Asia; India's conventional and security policies operated in a way to maximizing their weapons but on the other hand minimizing the Pakistan's security at the same time and rejected the proposals. It was ridiculous to pressurize Pakistan to sign the comprehensive test Ban treaty (CTBT) and return from full spectrum deterrence to strategic deterrence but India was expanding its ballistic and nuclear weapons which would demoralize region's stability. Pakistan developed nuclear weapons as strategic assets to safeguard the confidence of its citizens. During the early years of nuclear development, Pakistan has adopted the policy of minimum credible deterrence same as India, but with the passage of time now Pakistan adopt the full spectrum deterrence (Kayani, 2015). According Dr. Zafar Khan and Dr. Rizwana Abbasi from National Defense University, full spectrum deterrence in qualitative term was to protection the gaps in deterrence and addresses all forms of aggressions.

\subsection{Violation of Laws}

The deal violates the domestic and international law by USA, India and Pakistan. Unilateral termination of agreement can be prepared by United States to support India to conduct any nuclear test. Furthermore, this deal slightly violates and disrupts the conditions of International Atomic Energy Agency and Nuclear Suppliers Group. IAEA Safeguards cannot stop the transfer of nuclear technology by USA to India for civil purposes towards weapon development because a substantial section of India's nuclear complex would endure separate IAEA safeguards (Jaspal, 2008).After this treaty, five states obligate that not to transfer the technology of nuclear weapon to no-nuclear- weapon states. It also obligates that nuclear states are not transfer any type of nuclear explosive devices and their technology to any non-nuclear countries (Sokolski, 2010).

This deal violates the Nuclear Proliferation Treaty, which prevents the signatory state to transfer technology and material to another state. This deal also disrupts the decisions of NPT in which production, new supply or transfer of fission material and technology, disarmament and nonproliferation are the main objectives of NPT. Moreover, under this agreement of NPT no one nonnuclear state acquires or produces the nuclear weapons or other nuclear explosive 
devices (Ashraf, 2016). India and Pakistan tested the nuclear explosion in 1998 and both of states refused to sign the NPT.

The deal openly flouts the concrete steps and principles of NPT review conference 2000 for nuclear disarmament. Due to Indo-USA nuclear deal other nonnuclear states takes steps for the development of nuclear weapons and USA does not fulfill the means of 1995 and 2000 obligations of NPT. These incidents are threat for the integrity, universality and principles of the Nonproliferation Treaty. This cooperation further destabilizes the Missile Technology Control Regime (MTCR) even USA is also a member of this agreement. The aim of this agreement is to stop the proliferation of weapons and unmanned delivery system and Indo-USA nuclear deal potentially violates the principles of MTCR (Jaspal D. Z., 2015). Moreover, the deal could damage the guidelines of committee of 34-members which were working to suppliers group to transfer the nuclear material for weapons. Now India is the single state that can trade in nuclear materials without being a member on NPT. Due to deal with United States, India stabilizes her status as nuclear state and not agreed to sign the Nonproliferation treaty. India got participation in community of international nuclear events of nonproliferation and disarmament without any problem because India had a full support from United States of America after the nuclear cooperation. Furthermore, if India arises as a major power with permanent seat in United Nation Security Council than it has the power of veto that will manipulate and influence on Pakistan in international affairs (Khan, 2014).

\subsection{Impact on Economy}

India has more focus and sensitive toward Pakistan's spending on military and development of weapons rather than Pakistan is to India's. India is maintaining its superiority over its enemy but on the other side Pakistan spend more of its budget on the defense and security. Pakistan's Weapons of Mass destruction especially nuclear weapons are facilitated and provide the security to economic paces but not a source of economic deprivation. For the defense of Pakistan, the government is spending 11.6 per cent to Rs781billion in every coming 780 bnyear. The defense Minister is also wants to increase the defense budget in 2015-2016 (Syed, 2015). After signing of this deal by India and United States, Pakistan prefers to spend a large amount of finance from public sector to become a nuclear capable state. In future, these expenditures may increase on $19 \%$ from out of total budget as compared to leaving year in which $18 \mathrm{pc}$ expenditures at present. The defense budget is measured as ratio the GDP which shows the burden that put-on state economy. On the other side, the comparison between defense and national budget shows the money which is used for armed forces. Generally, Defense budget pie division, military would get Rs371bn amount of share from the defense budget, air force Rs164.24bn, a small part of defense budget for Navy is only Rs85bn and Rs160.7bn for defense establishment and Inter-Services intelligence (ISI). On the other hand, defense budget of India is USA \$38.35 billion that is more than six times of Pakistan's defense budget.

Expenditures of Forces

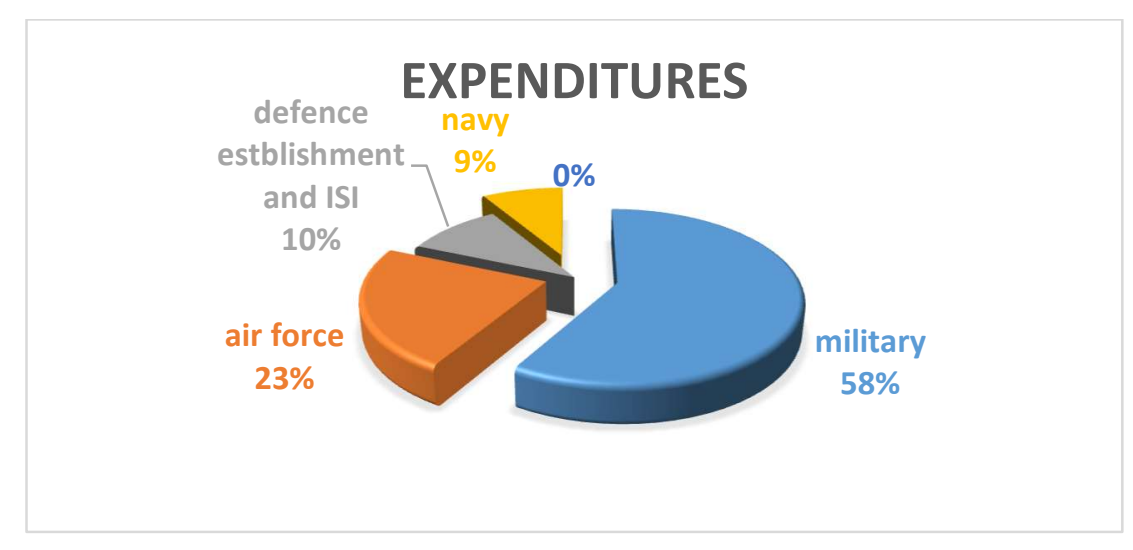

\subsection{Terrorist groups}

Another important factor is that Pakistan has threat from terrorist groups. This dramatic ascent of Taliban started in 1994 (Bokhari, 2003). But some horrible incidents are the victimized in the recent times not only in Pakistan but also in India. Basically, after this deal which was signed between India and United States, strong the India's place in South Asia but create many security concerns for Pakistan (Ahmad M. A., 2014). After the security and political challenges there is a misconception that the nuclear security of Pakistan is weak. In 2009, four terrorist attacked GHQ Rawalpindi 
in which six army soldiers martyred and terrorist kidnap some security personnel near check post No 2 (Rao, 2009). From army resources, this attack had been taken by India in return of attack on Indian embassy in Kabul (Khan A. , 2009). Taliban attacked on Pakistan Mehran air force camp in Karachi. Somehow Involvement of India's intelligence agency RAW funded to the Tehrik-e-Taliban attacked on PAF Camp Peshawar. At that time Pakistan take steps and fighting against different terrorist groups like Tehrik-e-Nifaz-e-Shariat-e-Mohammadi, Laskar-e-Taiba, HarakatulMujahidin, Lashkar-e-Jhangvi especially Tehrik-e-Taliban Pakistan and some other external irritants. An alliance of tribally affiliated militant had started to recognize itself as Tehrik-e-Pakistan by 2003.

Taliban strengthen its position and created insurgency in Pakistan after USA pressure to cut off interference into Afghanistan. Due to afghan war, Pakistan faced much insurgency and inclination of afghan refugees that created harmful situation for Pakistan. The Inter-Services Intelligence (ISI), military organization of Pakistan, to take steps over those areas where refugees lived. Moreover, Pakistan faced insurgency in Baluchistan, Sawat and other parts of states. Pakistan scarified its military and civilian people and both eastern and western borders are not safe. From some resources, India was included in some terrorist activities that held recent years in Pakistan. So, this type of threat made it essential for Pakistan to improve its defense capabilities (Anwar, Rafique, \& Joiya, 2012).

Pakistan's participation in war against terrorism operation faced devastating economic and social disturbance. The economy of Pakistan improved in the first years because of financial inflows from the USA and other sources but the eruption of ethnicity extremism and uncertainty in society effected the economic growth of the country badly. The factor of extremism in Pakistan increased due to lack of education and economic deprivation in tribal and backward areas. (Butt \& Elahi, 2010). That's why government was incapable to spend money in the fields of health, education, irrigation and roads between local farms and market. Another problem is the internally displaced persons (IDPs). After joining the war on terror, Pakistan economy is suffering severely due to wasted opportunities of trade, growth and revenue of millions of dollars. Pakistan is facing political instability, militancy, terrorism in society (Ali, 2014).Pakistan's military are establishing the operation in all over Pakistan, such as Zarb-e-Azb, Rah-Haq, Zalzala, Sher-e-Dil, Rah-e-Nijat, Rah-e-Rast, Koh-e-Sufaid against terrorist groups. Due to this operations Pakistan affected the internal and external policies and exaggerated the future of Pakistan. Pakistan is the state who rapidly increasing its nuclear weapons and take substantial security measures to prevent and protect nuclear arsenals from world's most dangerous terrorist groups. According to Strategic Plan Division which manages the nuclear weapons those more than 25,000 troops has available to secure and guard Pakistani nuclear technology and stocks. Sites are equipped with wide barriers and detection system and nuclear weapons are stored separately to safe the weapons with locks to prevent unauthorized use, said by Pakistani officials (The Hindu, 2016). According to American think tank Howard, India's nuclear weapons security is weaker as compared to Pakistan because Pakistan has taken measures to secure its nuclear weapons.

\subsection{Power Imbalance}

Although India has renewed its defense and trade relations with US that Pakistan sees the Indo-USA nuclear deal will disturb regional power balance. Consequently, Pakistan has moved closer to its long-time ally with china to counter its cunning rival India that increasing economic and military domination in the region. On the other hand, India also increases its collaboration with china and China establishes its relationship with India. Due to Pakistan's friendship China will never take any chance to destroy its relationship with India. Pakistan has close relations with china which would become closer when China decided. This is happening only because of USA-India deal. In words of Khandekar, China will not go against the India to just because of Pakistan as a strategic balance and competitor(Deutsche Welle, 2016).India's submission for permanent member of United Nations Security Council was opposed by Pakistan. The United States president favored it. Although India has violated the United Nations Security Council resolutions of international peace and security, for instance Jammu \& Kashmir dispute.

\subsection{USA seeks Indian help to pressure Pakistan}

National assembly of Pakistan passed a law of military court that paved a way for the trails of terrorists and suspected persons. India-USA nuclear deal pressurizes the Pakistan for the trails of anti-Indian terrorist. President Obama said that Pakistan's nuclear weapon was fear of acquisition by any terrorist group like ISIS (Daesh). No doubt, Pakistan had got considerable leverage in economic terms from USA, because any reduction of any support from USA would undermine the Pakistani support to anti-terror operations. These operations are the primary way through which USA engaging herself with Pakistan. Pakistan always desired direct support from United States to solve the Kashmir Issue with India but USA always take decision in favor of India but India will never be taking any unilateral action against Pakistan because it would increase the chances of war between both countries. USA continues to bolters relations with 
India while India pressure USA impose restrictions on Pakistan to support for Lashkar-e-Taiba that involved in Mumbai attacks in 2008 and so on (Domínguez, 2015).

\section{Conclusion \& Recommendations}

The deal represents a step for the proliferation and armament between states of South Asia. It also allows for upsurge of nuclear weapons and testing. This deal denied the Nonproliferation Treaty's rules and regulations. This Indo-USA bounding is detrimental to international security because it is being recognized as tension, mistrust and violation of the spirit of international law and intergovernmental organizations. This could force other states to re-arrange their security due to Indo-USA nuclear deal and through this activating transformation in structures of regional alliance. This deal has a grave impact on Pakistan and South Asia. Basically, this Indo-USA nuclear deal is using to weaken the position of Pakistan as militarily and economically. The main objective of Pakistan has been to secure Pakistan's territorial integrity against any threat from its neighbor countries. At the back of this threat, basic reason is Indo-USA nuclear deal because this deal creates problematic environment for Pakistan. No partnership in international relations is built up without having shared motives and interest behind. While examining international political system, many examples of strategic partnership comes across, between different states. Although this deal is a civil nuclear deal for peaceful purposes but after Usage of uranium it still has ability to use for other nuclear purposes. Pakistan could be used all available options including a possible strategic alliance with Russia and China to secure its interests. For the stability in South Asia, must encouraging the process of track II diplomacy between India, Pakistan, China on nuclear issues. Moreover, needs to improve diplomatic and scientific relations. Pakistan has adopted the policy of flexible response through introduction of tactical nuclear weapons to maintain deterrence in the region. The rise of China in economic and armed fields, United States needs to maintain its hegemony and equilibrium in Asia. Now USA opened all the doors for India for military assistance. USA signs a deal with India on civil nuclear purposes because India is a single democratic state in South Asia which works for USA as a watch dog. But this deal encourages other states to attain nuclear weapons and supports nuclear states to transfer their nuclear technology to non-nuclear states. This will increase the vertical and horizontal proliferation which would activate arms race in region.

\section{There are different recommendations for Pakistan to reduce the impacts of this deal.}

- Pakistan should change the strategy with the self-assurance and develop its own strategic weapon capabilities without any alliance.

- Indian military interference in Afghanistan is creating disturbance for Pakistan on western borders of Pakistan. For the Pakistan as balancer state against India needs deliberate planning and sharp foreign politics. Pakistan is dignified at a crossroads, but if it plays its policies expertly than it can catapult itself to a position of powerful state of region.

- Pakistan requires building up its political administrative infrastructure and emphasis on the economy to produce resources for long term policy. By diplomatic channels Pakistan get the same immunities, which have been allowed to India by the United States on the name of energy crises.

- Moreover, international society needs to wok collectively to counter the threat of extremists and terrorist activities. Pakistan should control and solve the internal issues and prevent the interference of external factors.

- Political policies and military strategy are two methods to prevent national threat. Pakistan should be improving its political ties with other states because today's friend can be tomorrow's friend.

- Pakistan must increase its ties with Muslim countries especially Central Asian States for the sack of its own interest and Islamization. Additionally, Pakistan should develop its ties and cooperation with Saudi Arabia and Iran. Through this cooperation Pakistan, Iran and Saudi Arabia will make large Islamic bloc in the world because both Iran and Saudi are oil rich countries.

\section{References}

Akhtar, S. (2012). Dynamics of USA-Pakistan Relations in the Post 9/11 Period: Hurdles and Future Prospects. International Journal of Humanities and Social Science, 2(11).

Ali, k. Z. (2013). Indo-US Civilian Nuclear Deal: The Gainer and the Loser. A Research Journal of South Asian Studies, 28(1), 241-251.

Bajoria, J., \& Pan, E. (2010, November 5). council on foreign relations. Retrieved from http://www.cfr.org/: http://www.cfr.org/india/us-india-nuclear-deal/p9663 
Bokhari, S. S. (2011). India-United States Strategic Partnership:Implications for Pakistan. Berkeley Journal of Social Sciences, 1(1).

Council, S. (1998, June 6). United Nations. Retrieved from http://www.un.org/press/en/1998/sc6528.doc.htm

Fani, M. I. (2009). The Indo- US Strategic Partnership in Post 9/11: Implication for Pakistan. Diffusion of Information Technology .

Gledhill, A. (1964). The Republic of India: The Development of Its Laws and Constitution. london: Stevens.

Hosur, P. (2010). The Indo-US civilian nuclear agreement. International journal, 435-448.

Jabeen, M., \& Ahmed, I. (2011). Indo-US Nuclear Cooperation. A Research Journal of South Asian Studies, 26(2), 411-429.

Jangir, D. S. (2012). INDO - US Nuclear Deal and 123 Agreements. International Journal of Scientific and Research Publications, 2(10).

Jangir, s. k. (2012). INDO-US Nuclear Deal and 123 Agreements. International Journal of Scientific and Research Publications, 2(10).

Jaspal, D. Z. (2007). The Indo-US strategic relationship and Pakistan's security. ISSI.

Jaspal, D. Z. (2011). Ballistic Missile Defense: Implications for India-Pakistan Strategic Environment. NDU journal, 1-26.

Karat, P. (2007). The Indo-US Nuclear Deal:Struggle to Defend National Sovereignty. The Marxist, 23(2).

Kimball, D. G., McGoldrick, F., \& Scheinman, L. (2008, July 30). Retrieved from https://www.armscontrol.org.

Kronstadt, K. A. (2007). India-U.S. Relations. CRS Report.

M.Goswami, \& S.Sahoo. (n.d.). International Thermonuclear Experimental Reactor: A Thermonuclear Future.

Mian, Z., Nayyar, A. H., Rajaraman, R., \& Ramana, M. V. (2006). Fissile Materials in South Asia and the Implications of the U.S.-India Nuclear Deal. Science and Global Security, 114-143.

Mistry, D. (2014). The US-India Nuclear Agreement. Cambridge University Press.

Mohan, C. R. (2016, April 14). http://indianexpress.com/. Retrieved from indianexpress.

Müller, J. (2009). The Signing of the U.S.-India Agreement Concerning Peaceful Uses of Nuclear Energy. Göttingen Journal of International Law, 1, 179-198.

Mustafa, A. (2013, June 20). Retrieved from http://blogs.tribune.com.pk/.

Mustafa, M. Q. (2014). CTBT: A critical evaluation from a Pakistani perspective. ISSI.

Sharma, S. D. (2008). The Making of the US-India Nuclear Accord. global asia, 4(3), 64-70.

Shourie, A. (2006, december 20). WordPress.org. Retrieved from Arun Shouries Articles: https://arunshourie.wordpress.com/2008/05/28/\%E2\%80\%98but-you-must-wait-for-the-123agreement $\% \mathrm{E} 2 \% 80 \% 99 /$

Squassoni, S. ( 2006). India's Nuclear Separation Plan: Issues and Views. CRS Report.

Sultan, A. (2006). Indo - US Civilian Nuclear Cooperation Agreement Implications on South Asian Security Environment. 